\title{
Risperidone: An Example of the Antipsychotic Treatment According to the Susceptibility Genes \\ Werner $\mathrm{FM}^{* 1,2}$ and Coveñas $\mathrm{R}^{2}$
}

${ }^{1}$ Higher Vocational School of Elderly Care and Occupational Therapy, Euro Academy Pößneck, Pößneck, Thuringia, Germany

${ }^{2}$ Laboratory of Neuroanatomy of the Peptidergic Systems (Lab. 14), Institute of Neurosciences of Castilla y León (INCYL), University of Salamanca, Salamanca, CastillaLeón, Spain

"Corresponding author: Werner FM, Laboratory of Neuroanatomy of the Peptidergic Systems (Lab. 14), Institute of Neurosciences of Castilla y León (INCYL), University of Salamanca, Salamanca, Castilla-León, Spain, Tel: +34/923/29 44 001856; E-mail: felixm-werner@versanet.de

Received date: February 19, 2019; Accepted date: February 25, 2019; Published date: February 28, 2019

Copyright: @ 2019 Werner FM, et al. This is an open-access article distributed under the terms of the Creative Commons Attribution License, which permits unrestricted use, distribution, and reproduction in any medium, provided the original author and source are credited.

\section{Editorial}

Schizophrenia is a chronic psychiatric illness which affects about $1 \%$ of the population. In the prodromal phase, symptoms such as depression, social withdrawal and mutism occur during about 7 years, till an acute manifestion with symptoms as hallucinations, illusions and paranoia appears [1]. Since the proposal of the dopamine hypothesis, a multi-neurotransmitter system in different brain regions has been suggested. An increased dopamine release, via the dopaminergic $\mathrm{D}_{2}$ receptor, and an augmented serotonin release via the serotonergic $5-\mathrm{HT}_{2 \mathrm{~A}}$ receptor occur in in the involved brain areas, e.g. ventral tegmental area. In preclinical studies, ketamine, an antagonist of the NMDA (N-methyl-D-aspartate) receptor can cause schizophrenia-like symptoms, which can be ameliorated with $5-\mathrm{HT}_{2 \mathrm{~A}}$ antagonists, but not by first-generation antipsychotic drugs which block $\mathrm{D}_{2}$ receptors. The search for susceptibility genes has been developed, and some risk genes are known [2,3]. In most cases, schizophrenic patients are treated with first-generation antipsychotic drugs and more often with newer antipsychotic drugs which block, with different affinities, the dopaminergic $\mathrm{D}_{2}$ receptor and the serotonergic 5- $\mathrm{HT}_{2 \mathrm{~A}}$ receptor [4]. In schizophrenia, the current discovered susceptibility genes are the following: COMT (catechol-Omethyl-transferase), which is an enzyme that shows a decreased activity and catalyses the catabolism of dopamine; MAO (monoamine oxidase), which is also an enzyme with a reduced activity and catalyses the breakdown of dopamine; GAD 67 (glutamate decarboxylase), which indicates a diminished activity of GABAergic neurons, and the genes dysbindin and neuregulin, which refer to a declined activity of NMDA glutamatergic neurons [2].

In the mesolimbic system, the neural network is pointed out, as seen in Figure 1, dopaminergic neurons, which have a high activity according to genes (e.g., COMT, MAO), apply a postsynaptic excitatory potential via D2 receptor to GABAergic neurons, which according to the genes dysbindin-1 or neuregulin-1 exert a weak presynaptic inhibitory potential, via NMDA receptors, upon serotonergic neurons. The serotonergic neurons exert a strong activating potential via $5-\mathrm{HT}_{2 \mathrm{~A}}$ receptors upon GABAergic neurons, which apply a weak presynaptic inhibitory potential upon dopaminergic neurons, which is encoded in the GAD 67 gene $[2,3,5]$. In the VTA, dopaminergic neurons transmit a postsynaptic excitatory potential to other dopaminergic neurons (A10 cell group) and serotonergic neurons apply an activating potential to other serotonergic neurons. Both neurons send an activating potential to each other and thus they increase dopamine and 5-HT release [5].

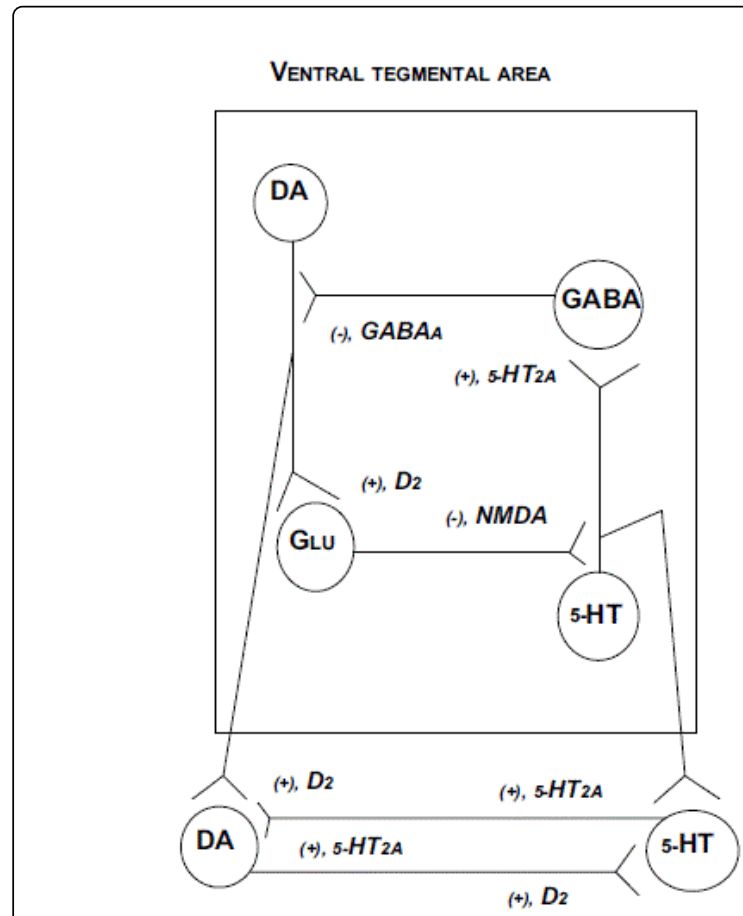

A10 CELL GROUP

Figure 1: Neural network in the brain areas involved in schizophrenia. 5-HT: serotonin; DA: dopamine; GABA: gammaaminobutyric acid; Glu: glutamate. $5-\mathrm{HT}_{2 \mathrm{~A}}: 5-\mathrm{HT}_{2 \mathrm{~A}}$ receptor of the serotonin (5-HT) receptor; $\mathrm{D}_{2}: \mathrm{D}_{2}$ receptor of the dopamine (DA) receptor; $\mathrm{GABA}_{\mathrm{A}}: \mathrm{GABA}_{\mathrm{A}}$ receptor of the $\mathrm{GABA}$ receptor; NMDA: $\mathrm{N}$-methyl-D-aspartate receptor.

The second-generation antipsychotic drug risperidone blocks dopaminergic and serotonergic receptors and has a specific affinity for the $\mathrm{D}_{2}$ receptor [4]. In an explorative study, 690 schizophrenic patients and 430 healthy subjects received a risperidone treatment for 8 weeks. Blood samples were taken and single nucleotide polymorphisms of the COMT risk gene and of the dopamine receptors were examined by the polymerase chain reaction. A correlation analysis was conducted 
Citation: Werner FM, Coveñas R (2019) Risperidone: An Example of the Antipsychotic Treatment According to the Susceptibility Genes. J Cytol

Page 2 of 2

between the schizophrenia related genes and the improvement of positive and negative schizophrenic total score scale. A single nucleotide polymorphism referring to the COMT enzyme was related with a significantly better improvement of positive and negative symptoms in schizophrenia [6].

Does efficacy of the different antipsychotic drugs depend on the risk genes in schizophrenic patients?

\section{References}

1. Huber G, Gross G (1989) The concept of basic symptoms in schizophrenic and schizoaffective psychoses. Recenti Prog Med 80: 646-652.
2. Werner FM (2006) Schizophrenia: from the genetic localization to the cellular mechanism. Klin Neurol 37: 19-20.

3. Collier DA, Li T (2003) The genetics of schizophrenia: glutamate not dopamine? Eur J Pharmacol 480: 177-184.

4. Werner FM, Coveñas R (2014) Safety of antipsychotic drugs: focus on therapeutic and adverse effects. Expert Opin Drug Saf 13: 1031-1042.

5. Werner FM (2014) Brain centers involved in schizophrenia. J Cytol Histol 5: 5 .

6. Yijang H, Yan L, Xumei W (2017) Potential link between gene polymorphisms of catechol-O-methyltransferase and dopamine receptors and treatment efficacy of risperidone on schizophrenia. Neuropsychiatr Dis Treat 13: 2935-2943. 